the notes on the keyboard, in the same way Fig. II shows that the horse, at the moment when he falls back upon the earth, is supported only by one foot ; then, when the two diagonal feet strike the ground together in their turn, the horse has at this moment a triple support. Without the notation of paces we had certainly failed to distinguish this series of supports.

The gallop of the racecourse used generally to be considered as a pace of two steps, in which the horse struck the ground alternately with the two fore-feet and the two hind-feet. This gallop shows itself in the notation as a pace of four steps; the tracing dissociates the two forefeet and the two hind-feet, although they follow each other at a very short interval.

The transition from one pace to another, impossible to determine by direct observation, is clearly inscribed in Fig. I 2.

IV. Artistic Representation of the Horse and other Animals. - The artistic representation of animals requires a special and varied acquaintance with their peculiarities. Nothing can replace the patient study by which the painter or the sculptor acquires an anatomical knowledge of the limbs of animals and the aspects which they assume in different positions. But if the painter or the sculptor wishes to animate his work, if he wishes to show the horse putting forth its efforts in powerful traction, or to represent it urged rapidly forward in the race, it is necessary to have an exact acquaintance with different paces.

That which is true of the horse is equally so of other animals; but all present among themselves such great analogies in this respect, that if we are acquainted with the paces of the horse, we can represent those of any other animal.

The summary analysis we have just now made of the rhythms of steps in each pace is not yet sufficient to express the attitudes which represent them; we have as yet only examined in connection with these morements one of the two essential ideas. We are acquainted with the relations of time; it is necessary also to become acquainted with the relations of space, that is to say, to know at each moment in what place to find each of the members raised or planted upon the ground. Obliged to abridge this already long discourse, I will not tell you how one determines graphically the phases of the movement of a foot that is raised, but I will show you sum. marily how we determine the place where each foot is brought down. This indication is furnished by the imprint which the horse leaves upon the ground. M. de Curnieu, Capt. Raabe, and M. Lenoble du Teil have studied with particular care these imprints or tracks of the horse at different paces. The smooth sand of the sea-shore presents a surface admirably adapted for this study. Persons who have acquired the habit, easily decipher such imprints. But in order to render them easily read by every one, we have conceived the idea of giving a different form to the shoes of the fore-feet from those of the hind-feet by furnishing the latter with clamps. The principal paces represented by their tracks have been thrown together in Fig. 13, which I have borrowed from M. Lenoble du Teil. In combining with the idea of the rhythms, that of the place where each foot would be planted, the errors of attitude which disfigure so many chefs d'cuvres, would be avoided. You will, perhaps, say that few persons are capable of recognising faults of this kind. On this point one might repeat what Baron Dupin said with respect to perspective in its relation to the art of painting. "In proportion as exact knowledge becomes more widely diffused, many faults which to-day only shock a small number, will shock the general public, and artists will no longer be able to perpetrate them with impunity."

Those artists who at the present time make such praiseworthy efforts for the correct representation of the horse, would find great assistance from making use of the notation of paces. Let us see in what way. Take, for example, the notation of the trots. We all grant, in the first place, the possibility of dividing each step into a series of successive instants, ten or twenty, for example. At each of these instants the horse will have a different attitude, but throughout the time the limbs diagonal to each other will be executing the same motions at the same time.

Let us take one of these instants at random and mark it by a vertical line (Fig. 14). The notation shows us that at this instant the right hind-foot and the left forefoot are planted upon the ground, but that the right forefoot and the left hind-foot are still raised, and are about to be set down. That is exactly as represented in the figure.

Upon another notation (Fig. 15) we have chosen another instant, that in which the horse is suspended in the air, and when the hind-feet have already quitted the ground, whilst the fore-feet do not yet touch it.

Let us pass on to the pace of the gallop (Fig. 16). The moment chosen is that in which the horse falling back upon the hind-foot has just made his first step. Two limbs in diagonal relationship are about to strike the ground at the same time, namely, the right hind-foot and the left fore-foot, represented as already being lowered towards the earth. As to the right fore-foot, that will strike the ground last, accordingly it is shown as still the furthest removed from the earth.

With regard to the foot pace, which is the most difficult to explain, three instants have been selected on the notation: $x$. That where the hind-foot is about to be raised, and where the fore-foot is in the middle of its elevation (Fig. 17). At this moment there are three feet at rest, which only takes place with horses when making an effort of traction. 2. The moment in which the two diagonal feet are raised, the one having just quitted the ground and the other being about to be placed upon it. (Fig. 18). 3. The moment when the animal, supported by two feet on the same side, is raising one of its fore-feet. and is about to set down one of the hind-feet on the same side (Fig. I9).

These pictures have no other pretensions than to be correct as regards the position of the members; it would be the artist's duty to add elegance of form. But is it not something to have a simple and sure means of representing a horse in any pace and in any phase of the steps in that pace? The employment of the graphic notation would give to the artist the double advantage of representing the paces. with truthfulness and of varying them to an extent almost illimitable. Now, imperfection in art is not displayed solely by errors that may be committed, for too often an. artist who is thoroughly acquainted with a correct attitude repeats it with regrettable monotony.

(To be continued.)

\section{GEOLOGY OF NATAL AND ZULULAND}

SOME years have now passed since Mr. Griesbach gave to the Geological Society his paper and map illustrating the geology of Natal and the borders of Zululand. Passing events now give to his investigations the greatest interest, not simply due to the possible light that may be thrown on unsolved, or partly known, problems by the sojourn in that area of the contingent that has lately left our shores, but from the fact that the safety and success of our forces in great measure depends on the surface contour and physical character of the country to be traversed, which are necessarily directly dependent on its geological structure.

Few can have studied a geological map, without noticing the close connection between long lines of escarpment and belts of level plains with particular rocks, or noticing the marked uniformity in direction of strike of geological formations over large portions of the earth's surface; rock series after rock series plunging beneath its neigh- 
bour, and disappearing from view, only to be succeeded by bigher and higher strata above them. No better example of this could well be found than the map of Natal of Mr. Griesbach; the rocks all run parallel to the sea-coast, striking into the Zulu territory, and dipping steadily the one after the other -into high ground, forming the watershed between the Indian and Atlantic oceans. The eastern or seaward beit about fifty miles in wiath, consists of ancient mica-schists, resting on granite and gneiss seen at the bottom of the deeper valleys, the whole surnounted by the: "Table Mountain Sandstone," of carboniferous age, forming extensive plateaux, lying perfectly flat on a horizontal surface of clay-slate, and broken by lines of fault, into a series of steps, plateaux rising abore plateaux, with precipitous sides to a height of 2,300 feet between the sea and Pietermaritzburg, where the country again descends to 2,080 . These tablelands are covered with extremely poor soil, supporting a dense grass vegetation, on which feed numerous herds of cattle; not a shrub occurs to enliyen the endless uniformity of the scene, broken only by the ravines formed by the rivers cutting down through the sandstones to the granite and old rocks beneath, of ten forming precipitous cliffs several thousand feet high, the vertical drop, from the Krantzkop Mountain to the River Tugela being nearly 3,800 feet. The top of this mountain is composed of melaphyre; these melaphyre grcenstones contain copper ores and strike south-westwards to the Ingeli range in Kaffirland.

At Pietermaritzburg, the next belt of country commences, the town being built on the basement beds of the Karoo formation, belonging to the Dicynodon beds of South Africa, of triassic age, the name being given from the "karoos," or immense plains of the interior, forming the largest part of South $\Lambda$ frica, including the elevated tract of "Kalahari, the Free States, and the Transvaal, as vell as the country to the north, as far as Limpopo." They are present in the Zambezi, and rise to a height of 12,000 feet in Mont-aux-Sources, in the Drakenber: Mountains: The base of the Karoo series rests unconformably on the carboniferous table mountain sandstone, and consists of large angular blocks of transported granite, greenstone, and gneiss, in a matrix of clay and grit. They occupy a large area, and pass under plant-bearing shales These boulder beds have been ascribed a glacial origin by Dr. Sutherland, Surveyor-greneral of Natal. Mr. Givesbach points out the overlying plant-beds correspond to the plant-beds of Southern India, associated with Dicynodon remains, and also resting on a boulder bed (Talchir group).

The great Karoo plains, Dr. Grey is inclined to regard as the bed of an inland sea; salts of soda predominate larsely in the salines of the soil, and assist in forming the "background" of this region (sandy soil, with salt, carbonate of suda, and some salts of magnesia and alumina). It; strface forms the sweet-grass country of the Dutch "Zout-Veldt," yielding the valuable Karoo plant (Adenchara parifiora). In this tract the clmate is most salubrious, and the higher the country ascends the more fruitful is the ground. The ycllow wood fiourishes, wheat and Furopean fruits flourish, and the cold of the winter, though not so severe as that of northern Europe, braces the European settler, and agrees with his constitution.

Fringing the Natal shore, there is a narrow belt of the Karooformation, resting unconformably on the tablemountain sandstones and older rocks, so that the latter form an excestingly low and flat-topped anticlinal arch, throwing off the Karoo beds on either side. Landward these rise (0) the Drakenberg, seaward they have for the most part bcen denuded away, though their presence in Southern India points to the former extension over what is now the Indian Ocean of a series of lakes fringed by lands covered with plant growths, extending over Southern India, and parts of South Africa. The investigations of Mr. Blan- ford in Southern India support the views of Prof. Huxley and Mr. Sclater as to the existence of an extending submerged mesozoic continent, "Lemuria," which was shadowed forth in Mr. Darwin's researches on coral reefs. Mr. Blanford comments strongly on the great relation between the plants of the Indian and Australian (New South Wales). coalfields, many of the species beingr identical, the two localities being no less than 5,55 o mile. apart. In India these plant-beds rest on the supposed glacial (Permian?) beds of the Talchir group, the included scratched blocks being often forty-two feet in circumference.

The Karoo boulder bed is described by Dr. Sutherland as containing well-scratched blocks, inclosed in a material which has since been metamorphosed, and resting on scratched old silurian sandstones. The characters of the various members of the Karoo series is well capitulated by Prof. Rupert Jones in Mr. Ralph Tate's paper on South African jurassic marine mollusca; the sequence being : Stormberg beds (Huxley);. Beaufort Beds; Koonap beds, and Ecca beds. The Beaufort beds most closely correspond to the Dicynodon beds of India, the boulder beds in both countries, according to Mr. Blanford, being pre-triassic, and he carries back his Indooceanic continent to Permian times, and extending up to a late jurassic epoch-South Africa, India; and Australia being connected at the early part of the period; Africa and India, up to the end of the miocene.

In 1824, some caves cilled Izinlluzabalungu (white men's houses) were discovered by Mr. Fynn to be fossiliferous; the name, given by the natives, was due to shipwrecked sailors having taken up their abode in them. In 185 I Capt. Garden had his attention called to these fossils, especially some gigantic Inocerami, two feet by one foot, by his servant, named Thomas Souton, a Private in the 45th Regiment, after whom one of the fossils obtained was named by Mr. Baily, who examined them at the reguest of the late Prof. Furbes. The deposit occupies a small tract on the south end of the colony, and, as $\mathrm{Mr}$. Baily pointed out, may be correlated with the lower cretaceous of Southern India, one species Pecten quin quecostratus being common to the Finglish greensand. The investigations of Mr. Griesbach have largely added to the number of the species, and supported Mr. Baily's conclusions, twcenty two of the species occurring in India, thirteen being peculiar. Another patch of cretaceous rocks occurs at St. Lucia Bay, in Zululand, resting unconformably on the Karoo strata.

At the close of the jurassic period, the Indo-oceanic continent was submerged beneath a shallow cretaceous sea, surrounded by coasts, covered with vegetation, extending from India to Natal. At the close of this epoch elcvation commenced, and is probably still going on, as raised beaches, coral reefs, and oyster banks may be seen twelve feet above the sea. Through this action the Port of Durban must inevitably be silted up, which will be the fate of most of the ports on this coast, except the large port of Delagoa Bay, which is naturally clean swept by the north and south Mozambique current, which has gradually hollowed out the Bay.

Chas. E. IDE RANCE

\section{OUR ASTRONOMICAL COLUMN}

PRIZES OF THE: PARIS ACADEMY.-At the annual public sitting of the Academy of Sciences at Paris, last week, the medal on the foundation of Lalande was awarded to M. Stanislas Meunier for his researches on the constitution of meteorites, which, in the opinion of the Commission appointed for the consideration of clains, have led to results that occasion surprise, but at the same time appear justified by M. Meunier's investigations. Astronomers had followed with interest the labours of M. Daubrée, who has contributed so much to establish 